\title{
Gümüş iyon katkılı kalsiyum fosfat esaslı antimikrobiyal özellikli biyoseramik yapay kemik dokusu
}

\author{
Silver ion doped calcium phosphate based bioceramic antimicrobial \\ synthetic bone tissue
}

\author{
Nusret Köse \\ Eskişehir Osmangazi Üniversitesi Tıp Fakültesi, Ortopedi ve Travmatoloji Ana Bilim Dalı, Eskişehir
}

\begin{abstract}
Bu buluş insanlarda ve hayvanlarda osteomiyelit ve implant ilişkili kemik enfeksiyonlarının tedavisi amacıyla kullanılabilecek yapay kemik doku malzemesi üretimi ile ilgilidir. En önemli özelliği kemik enfeksiyonlarında ortaya çıkan boşlukların, enfeksiyon ile birlikte aynı anda tedavi edilebilmesini sağlayabilecek olmasıdır. Genel olarak buluş konusu ürün, nanoteknolojik yaklaşımlar uygulanarak elde edilen gümüş iyon katkılı kalsiyum fosfat temel yapısına sahip anti-mikrobiyal özellik kazandırılmış biyouyumlu yapay kemik doku malzemesidir. Gümüş katkılı antimikrobiyal biyoseramiklerin üretiminde yaş kimyasal yöntem kullanılmıştır. Elde edilen seramik tozlar bifazik (HAP+TCP) ve trifazik (HAP+TCP+Biyocam) olup yapıya gümüş iyonu katılarak antimikrobiyal özellik kazandırılmıştır. Sentezlenen nano toz ile gözenekli yapı oluşturacak malzeme karıştırıldıktan sonra istenen boyutlarında yapay kemik doku malzemesi elde edilir.
\end{abstract}

Anahtar sözcülkler: osteomiyelit; yapay kemik doku; gümüş iyon; biyoseramik

\section{T. C. Türk Patent Enstitüsü'ne Patent Belgesi için Başvuru Bilgileri[ ${ }^{1]}$}

Başvuru bilgileri Tablo 1'de gösterilmiştir. ${ }^{[1]}$

Tablo 1. Başvuru bilgileri ${ }^{[1]}$

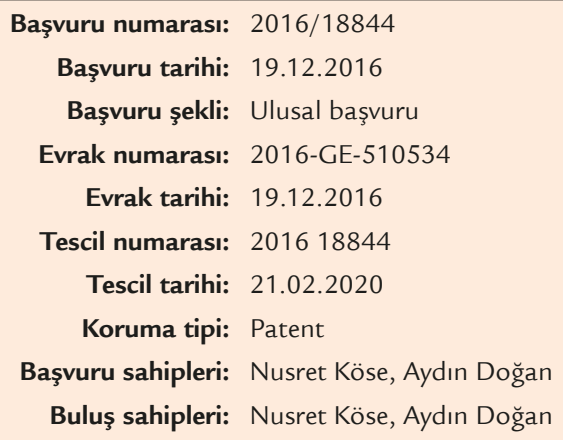

\begin{abstract}
The present invention relates to the production of artificial bone tissue material that can be used to treat osteomyelitis and implant-associated bone infections in humans and animals. The most important feature is that the gaps that occur in bone infections can be treated simultaneously with the infection. In general, the product is a biocompatible artificial bone tissue material with an anti-microbial property with a basic structure of calcium-phosphate doped with silver ion, obtained by applying nanotechnological approaches. Wet chemical method has been used in the production of silver-added antimicrobial bioceramics. The ceramic powders obtained are biphasic (HAP + TCP) and triphasic (HAP + TCP + Bioglass) and the silver ion has been added to the structure to gain antimicrobial properties. After mixing the synthesized nano powder and the material that will form a porous structure, artificial bone tissue material in desired dimensions is obtained.
\end{abstract}

Key words: osteomyelitis; artificial bone tissue; silver ion; bioceramic

\section{PATENT BELGESI - No: TR 201618844 B}

\section{Buluşun ilgili Olduğu Teknik Alan ${ }^{[1]}$}

"Bu buluş insanlarda ve hayvanlarda osteomiyelit ve implant ilişkili kemik enfeksiyonlarının sağaltımı sırasında, kemik enfeksiyonlarında ortaya çıkan boşlukların enfeksiyon ile birlikte tedavi edilebilmesini sağlayabilecek, nanoteknolojik yaklaşımlarla üretilmiş, biyouyumlu, antimikrobiyal özellik kazandırılmış gümüş iyon katkılı kalsiyum fosfat temelli yapay kemik doku malzemesinin geliştirilmesi ile ilgilidir."

\section{Tekniğin Bilinen Durumu[ ${ }^{[1]}$}

"Kemik enfeksiyonları kas-iskelet sistemi cerrahisinde en önemli sorunlardan birisidir ve bu sorun tüm dünyada yaygın olarak görülebilmektedir. Sıklıkla biyolojik dokularda bulunan proteinler mikroorganizmaların implant yüzeyine ya da kemik

- İletişim adresi: Prof. Dr. Nusret Köse, Eskişehir Osmangazi Üniversitesi Tıp Fakültesi, Ortopedi ve Travmatoloji Ana Bilim Dalı, Eskişehir Tel: 0555 - 3112091 e-posta: drnkose@gmail.com ORCID iD: 0000-0002-1517-9635

- Geliș tarihi: 9 Kasım $2020 \quad$ Kabul tarihi: 26 Kasım 2020 
yüzeyine tutunmasını kolaylaştırır. Yüzeyde birikmeye başlayan bakteriler biyofilm tabaka tarafindan çevrelenir. 24 saat içerisinde bir implant yüzeyinde ya da ölü kemik yüzeyinde tam bir biyofilm tabakası oluşabilir. Bu biyofilm tabakası içindeki mikroorganizmalar yavaş yavaş çoğalırlar ve hücresel ve hümoral bağısılklık sistemlerine karşı koyarlar. Bu halleri ile antibiyotiklerin penetrasyonunu engelleyerek antibiyotiklere karşı çok daha dirençli olurlar. Mikroorganizmalar tarafindan oluşturulan kemik enfeksiyonları sıklıkla oluşturdukları enflamatuar reaksiyonlar nedeniyle kemik yıkımına yol açarlar. Hastalıkı ya da hasar görmüş kemik dokularda kemik rejenerasyonunu sağlamak için kemik greftlerine gereksinim olacaktır.

Kas-iskelet sistemi cerrahisinde kemik yapımını ve iyileşmesini uyarmak ve kemik boşluklarını doldurmak için kemik mineral kompozisyonuna benzerliği ve kemik dokusu gibi gözenekli, biyodegredibl olma, biyoaktif ve osteokondüktif olma özelligine sahip hidroksiapatit (HA) ve trikalsiyum fosfat (TCP) temelli yapay kemik greftleri biyomalzeme olarak sıklıkla kullanılmaktadır. U.S. Patent No. 6,991,803, bu tip kemik greftlerine örnek olarak gösterilebilir. Bu ve benzeri gözeli yapıdaki kalsiyum fosfat temelli yapay kemik greftlerin yapısına biyocam eklenerek malzemenin biyoaktivitesi arttırılmış ve kollojen gibi polimer ekleyerek uygulamasının kolaylaştırılması gibi özellikler eklenerek daha iyi hale getirilmiştir (U.S. Patent No. 7,534,451).

Kemik enfeksiyonlarında enfeksiyonu ortadan kaldırırken aynı zamanda ortaya çıkan boşlukların doldurulmasını sağlayacak kemik rejenerasyonuna katkı sağlayacak biyomalzeme sistemlerinin geliştirilmesi önemli bir gereksinimdir”.

\section{Buluşun Çözümünü Amaçladığı Teknik Problemler ${ }^{[1]}$}

"Günümüzde farklı özelliklere sahip antibiyotik emdirilmiş yapay kemik greftleri vardır (US 7923019 B2 ). Bunlar farklı antibiyotiklerin uygulanabilmesi ve emilebilir olmaları nedeniyle yararlı olmakla birlikte, sonuçta antibiyotiklerle birlikte kullanıldığından ve bu antibiyotiklerin salınımının matriksin degredasyonuna değil diffüzyon kontrolüne bağlı olması, mikropların bu antibiyotiklere karşı direnç geliştirmesi, ayrıca bu biyoçözünür malzemelerin de yük taşıyamama, uygulama sonrası içsel kimyasal uyumsuzluk nedeniyle sertleşememe ve bozunmaları sırasında ortaya çıkan yan ürünler nedeniyle olguların bir kısmında inflamasyon ve buna bağlı fistüle yaralara neden olma olasıllğı gibi olumsuzluk görülebileceği bildirmiştir. Bu nedenlerle etkinlikleri sınırlı olmaktadır.

Antibiyotik olmayan antimikrobiyaller bu aşamada önemli bir alternatif oluştururlar. Titanyum üzerine uygulanmış gümüş içeren hidroksiapatit (HA) kaplamaların osteoblast ve epitel hücrelerin aktivitelerini bozmadan bakteri adhezyonu ve çoğalmasını etkili bir biçimde inhibe edebildiği gösterilmiştir. ${ }^{[2,3]}$ Hayvan çalışmalarında gümüş kaplanmış protez ve implant uygulamalarının enfeksiyon görülme olasılığını azalttığı ortaya konmuştur. ${ }^{[4,5]}$ Gümüş, bakteriyel tutunmayı önlemesi, geniş antibakteriyel spektrumu (hem gram negatif, hem pozitif bakteriler) uzun süreli antibakteriyel etkisi ve direnç gelişimine daha az eğilimli olması ile ve düşük yan etkisiyle bilinen bir maddedir.

Literatürde gümüşün antimikrobiyal etkinliği ve toksisitesi ile ilgili çelişkili yayınların görülmesinin olası nedeni, gümüşün dozu ve veriliş biçimi (metalik gümüş, iyonik gümüş, nanopartikül yapıda gümüş) ile ilişkilidir. Ortopedi literatüründe gümüş kullanımı daha çok implantların elemental gümüş ile kaplanması biçiminde hastaya uygulanması şeklinde olmuştur. ${ }^{[6]}$ (US 20130202670 A1) Gümüş iyonunun (Ag+) antibakteriyel özelliği metal halinden (Ag) çok daha etkilidir. Bakteriyel DNA'ya bağlanarak fosfat ve süksinat uptake' $i$ gibi birçok önemli transport yolunu engeller ve hücresel oksidasyonu bozar. Hücre zarı ve içeriğini bozar. Bakteriler yanında mantar ve virüsler üzerine de etkilidir. Guo ve arkadaşları 2016 yılında farelerde yaptıkları çalışmalarında intravenöz olarak enjekte ettikleri gümüş iyonunun değil, nanogümüş partiküllerin vasküler endotel hücrelerinde ROS (serbest/reaktif oksijen radikalleri) seviyesinin artışıla uzun dönemli organ toksisitesine yol açtığını göstermişlerdir. ${ }^{[7]}$

Hidroksiapatit, TCP ve biyocam gibi biyoaktif bir materyal ile birlikte gümüş iyonu kullanılırsa hem osteointegrasyonu yüksek, hemde antimikrobiyal etkinliği olan bir malzeme elde etmiş oluruz."

\section{Buluşun Kısa Açıklaması ${ }^{[1]}$}

"Bu buluşun amacı, insanlarda ve hayvanlarda osteomiyelit ve implant ilişkili kemik enfeksiyonlarının tedavisi amacıyla kullanılabilecek, kemik enfeksiyonlarında ortaya çıkan boşlukların enfeksiyon ile birlikte tedavi edilebilmesini sağlayabilecek, nanoteknolojik yaklaşımlarla üretilmiş, biyouyumlu, antimikrobiyal özellik kazandırımış gümüş iyon katkılı kalsiyum fosfat temelli yapay kemik doku malzemesinin geliştirilmesidir.

Buluş konusu antimikrobiyal özelliğe sahip gümüş iyon katkılı kalsiyum fosfat temelli yapay kemik dokusu elde etmek için öncelikle gümüş iyon katkılı seramik toz sentezlenir. Sonraki aşamada sentezlenen nano toz ile organik bağlayıcı ve gözenekli yapı oluşturacak malzeme karıştırılır ve malzeme istenen boyutlarında olacak şekilde biçimlendirilir.

$B u$ buluşun amacına ulaşmak için gerçekleştirilen gümüş iyon katkılı kalsiyum fosfat esaslı antimikrobiyal özellikli biyoseramik yapay kemik dokusu üretimi için bir yöntem ekli şekillerde gösterilmiş olup, bu şekillerden;

Şekil 1 - HAP, TCP ve biyocam fazlarına ait XRD örgü desenleri görülmektedir

Şekil 2 - Üretilen yapay kemik dokusunun genel görünüşüdür

Şekil 3 - Üretilen yapay kemik dokusunun kırık yüzey SEM görüntüleri verilmiştir.

Tablo 2 - Farklı sinterleme sıcaklıklarındaki XRF sonuçları verilmiştir." 


\section{Buluşun Detaylı Açıklaması[ ${ }^{[1]}$}

"Buluş konusu antimikrobiyal özelliğe sahip gümüş iyon katkılı kalsiyum fosfat temelli yapay kemik dokusu elde etmek için öncelikle gümüş iyon katkılı seramik toz sentezlenir. Sonraki aşamada sentezlenen nano toz ile organik bağlayıcı ve gözenekli yapı oluşturacak malzeme karıştırılır ve malzeme istenen boyutlarında olacak şekilde biçimlendirilir.

$B u$ tozun hazırlanmasında yaş kimyasal yöntem kullanıIır. Su bazlı çözelti içerisinde $\mathrm{pH}$ kontrol edilerek kimyasal çöktürme yöntemi kullanılır. Kullanılan malzemeler gümüş nitrat, kalsiyum hidroksit, ortofosforik asitten oluşmaktadır. Kalsiyum hidroksit ( $\mathrm{CaOH} 2$ ) ilk olarak saf su ile yaklaşık 1 saat karıştırıcı ile karıştırılır. Daha sonra gümüş nitrat saf su içerisinde çözülerek damla damla bu karışıma eklenir. Sisteme antibakteriyel özelliği kazandıran AgNO3 (gümüş nitrat) ilavesi ile beraber ortama yayılan Ag (gümüss) iyonlarıdır. Sonrasında ortofosforik asit yavaş yavaş elde edilen karışıma ilave edilerek $\mathrm{pH}$ değerleri ölçülür. Farklı pH değerlerinde Hidroksiapatit (HAP) ve trikalsiyum fosfat (TCP) gibi istenilen fazların oluşması sağlanır. Malzeme Içcerisinde toplam ağırlığı 0,001 den \%10 kadar farklı oranda $\mathrm{Ag}+$ iyonu içeren hidroksiapatit ve trikalsiyum fosfat karışımı bulunabilmektedir. Söz konusu bifazik biyoseramik yapıda, hidroksiapatit ve trikalsiyum fosfat 20/80, 30/70, 40/60 ve 50/50 oranlarinda bulunur.

Biyolojik ortamda fizyolojik gereksinimleri karşılamak amaciyla yapiya biyocam kompozisyonu eklenerek yapay kemik doku malzemenin reaksiyon kinetiği ve mekanik mukavemet değerleri optimize edilecek kompozisyonlar oluşturulur. Bu trifazik oluşumda Ag+ iyon katılı 4555 camı kullanılmakta olup. Toplam trifazik yapı içersindeki oranı $\% 1$ ile \%25 arasında değişir.

Hazırlanan çökelti filtreden geçirilir, daha sonra etüvde kurutulur ve istenilen boyuta getirmek için ögütülür. Üretilen tozların boyut ölçümü, morfolojisi ve kristal yapısı tane boyut ölçüm cihazı, taramalı elektron mikroskobu (SEM) ve $X$-ısınları difraktometresi (XRD) kullanılarak faz analizleri gerçekleştirilir. Şekil 1'de HAP, TCP ve biyocam fazlarına ait XRD örgü desenleri verilmiştir.

Sonraki aşamada sentezlenen nano toz ile organik bağlayıcı ve gözenekli yapı oluşturacak malzeme karıştırlır ve malzeme 1-5 mm boyutlarında olacak şekilde biçimlendirilir. İstenilen faz oranları ile birlikte tozun yaklaşık \%1'i kadar organik bağlayıcı olarak polivinil alkol (PVA) ilave edilir. Bununla birlikte yapıya farklı boyutlarda poly strene bilyeler ilave edilerek yapının boşluklu olması sağlanır. Hamur kıvamına getirilen malzeme yuvarlanarak küresel şeklinde ya da eşeksenli şeklinde yapay kemik doku malzemesi üretilir. Üretilen boncukların faz oluşumları ve yapının stabil olması için yaklaşık $1200-1300^{\circ} \mathrm{C}$ sıcaklıkları arasında (1-3saat) sinterlenir. Isıl işlem sürecinde yapının içine konulan poly strene bilyeler uzaklaşarak geride boşluklar bırakır ve poröz bir yapı oluşur
(Şekil 2). Sinterlenen boncukların kırık yüzey mikro yapıları ve oluşan boşlukların boyutları SEM (Taramalı Elektron Mikroskopu) ile incelenmiştir (Şekil 3).

Yapay kemik dokusunda elde edilen gözenekli yapı birbiriyle bağlantılı olup porozite \%50-70 oranında olup mikro ve makro gözeler 10-600 mikron boyut aralığındadır. Üretilen yapay kemik dokunun gözenek yapısı, gözenek dağılımı, gözeneklerin bağlantılı olup-olmadığı, üretim sıcaklık ve sürenin bu özelliklere etkileri porositemetre, taramalı elektron mikroskobu ve stereo mikroskop kullanılarak kontrol edilir. X-ray difraksiyon (XRD) yöntemi ile farklı sinterleme sıcaklıklarındaki kompozisyon ve kristal yapı ortaya konur. Tablo 1'de farklı sinterleme sıcaklıklarındaki XRF sonuçları verilmiştir.”

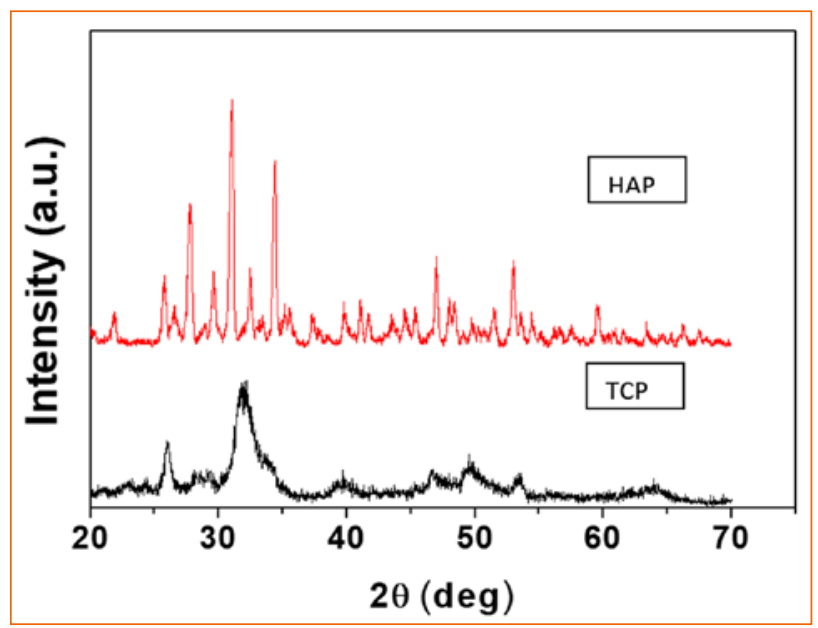

Şekil 1. HAP, TCP ve biyocam fazlarına ait XRD örgü desenleri.

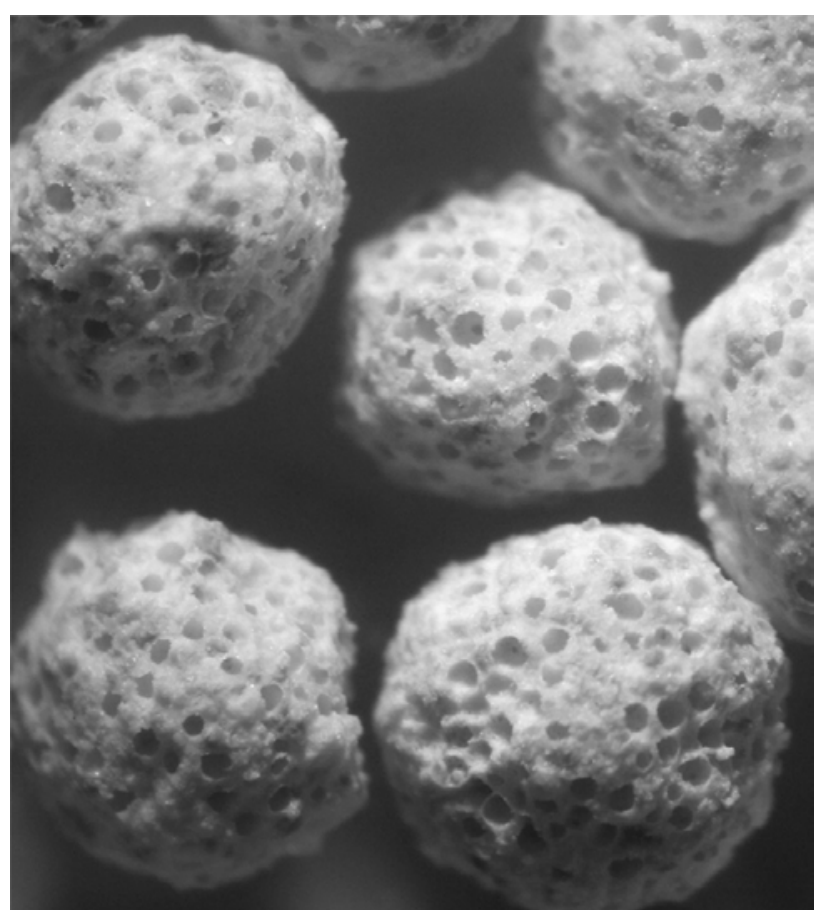

Şekil 2. Üretilen yapay kemik dokusunun genel görünüşü. 


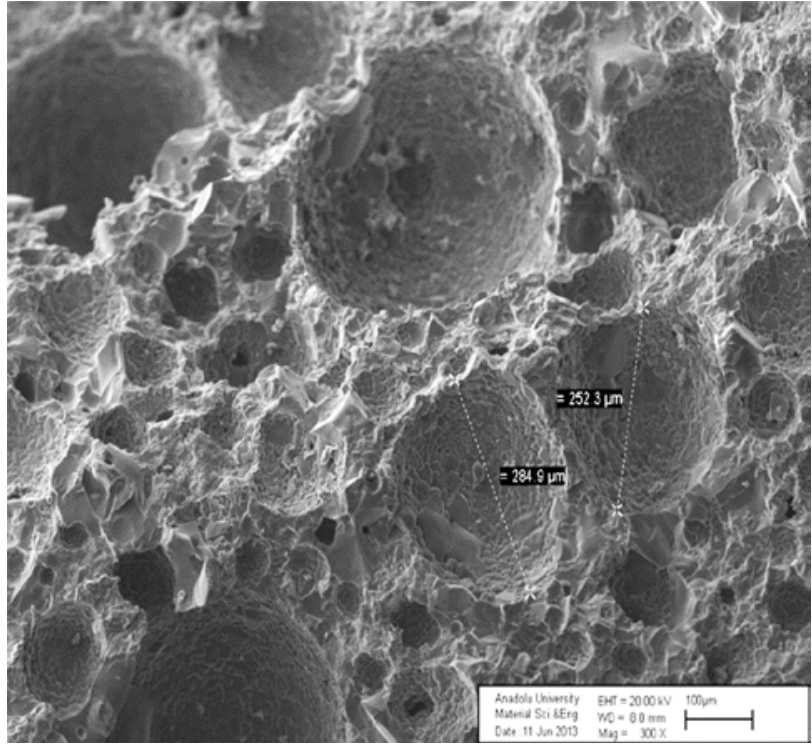

Şekil 3. Üretilen yapay kemik dokusunun kırık yüzey SEM görüntüleri.

Tablo 2. Farklı sinterleme sıcaklıklarındaki XRF sonuçları ${ }^{[1]}$

\begin{tabular}{lllllll}
\hline Name & initial & $\mathbf{9 0 0}$ & $\mathbf{1 0 0 0}$ & $\mathbf{1 1 0 0}$ & $\mathbf{1 2 0 0}$ & $\mathbf{1 3 0 0}$ \\
\hline TCP & $4,32 \mu g r$ & $4,31 \mu g r$ & - & $4,30 \mu g r$ & $3,97 \mu g r$ & $3,96 \mu g r$ \\
HAP & $4,97 \mu g r$ & $4,68 \mu g r$ & $4,6 \mu g r$ & $4,38 \mu g r$ & $4,1 \mu g r$ & -
\end{tabular}

\section{İstemler ${ }^{[1]}$}

"1. Buluş; enfekte kemik dokusu ve implant ilişkili enfeksiyonlarda enfeksiyonu ortadan kaldırırken aynı zamanda ortaya çıkan boşlukların doldurulmasını kemik rejenerasyonuna katkı sağlayarak gerçekleştirecek gümüş̧iyon katkılı, gözeli yapıda kalsiyum fosfat temelli antimikrobiyal kompozit malzemeden ibaret olan yapay kemik dokusu olup özelliği;

Aşağıdaki şu adımları;

a) Yaş kimyasal yöntem ile seramik tozun elde edilmesi

b) Karışıma kalsiyum hidroksit $\left(\mathrm{CaOH}_{2}\right)$, gümüş nitrat $\left(\mathrm{AgNO}_{3}\right)$ ve OFA (orto fosforik asit) ilave edilerek pH ölçümlerinin izlenmesi

c) Farklı pH ölçümlerinde hidroksiapatit (HAP) Trikalsiyum fosfat (TCP) gibi istenilen fazların oluşmasının sağlanması

d) Trifazik yapı oluşturmak istendiğinde yapıya biyocam (45S5) eklenmesi

e) Karışımın süzülüp kurutulması, öğütülmesi ve ısıl işlem $\left(900-1300^{\circ} \mathrm{C}\right)$ uygulanması d) Elde edilen seramik toz ile birlikte organik bağlacı olarak PVA (polivinil alkol) ve göze yapıcı olarak farklı boyutlarda polystyrene boncuklar kullanılması

e) Malzemenin $1100-1300^{\circ} \mathrm{C}$ arasında farklı sinterleme sürelerinde (1-3 saat) sinterlenmesi

içermesi ile karakterize ediliyor olmasıdır.

2. İstem 1'e uygun olan ve atıf yapılan bifazik kalsiyum fosfat kompozit malzeme, hidroksiapatit ve trikalsiyum fosfat karışımı olup 20/80, 30/70, 40/60 ve 50/50 oranlarında olduğu yapay kemik dokusudur.

3. İstem 1'e uygun olan ve atıf yapılan trifazik yapı içeren kompozit sistemde Ag+ iyon katılı 4555 camı kullanılmakta olup toplam trifazik yapı içersindeki oranı \%1 ile \%25 arasında değişmektedir.

4. İstem 1'e uygun olan ve atıf yapılan bifazik ve trifazik yapıların içerisinde gözenek oluşturmak için organik bağlacı Polivinil alkol \%1 oranında ve mikron boyutunda küresel polistren malzemelerden kütlece \%1 ve \%20 aralığında kullanılmaktadır.

5. İstem 1'e uygun olan ve atıf yapılan yapay kemik dokusunda elde edilen gözeli yapı birbiriyle bağlantılı olup porozite \%50-70 oranındadır ve oluşan gözeler 10-600 mikron boyutlarındadır.

6. İstem 1'e uygun olan ve atıf yapılan yapay kemik dokusunda 0,001'den \%10 ağırlı̆̆ına kadar Ag+ iyonu bulunabilmektedir."

\section{YAZARIN KONUYLA ILGILI ÇALIŞMALARI}

Kontaminasyon, organizmanın vücut dokularında bakteri, virüs, mantar ve parazit gibi mikroorganizmaların varlığı iken enfeksiyon, hastalığa neden olan, patojen olarak bilinen bu ajanların vücut dokularını istilası ve bunların çoğalması ile konakçı dokuların bu bulaşıcı ajanlar ve toksinlere karşı oluşturduğu reaksiyondur. Cerrahi alan enfeksiyonları (CAE) tüm cerrahi prosedürlerden sonra görülebilen yaygın bir komplikasyondur. Bu enfeksiyonlara genellikle cerrahi prosedür sırasında yaraya giren eksojen ve endojen mikroorganizmalar neden olur. Her türlü prosedürle ilişkili potansiyel bir komplikasyondur. Cerrahi işlem geçiren hastaların ortalama \% 11'inin etkilendiği bilinmektedir. Amerika Birleşik Devletleri Hastalık Kontrol ve Önleme Merkezleri (CDC), CAE'yi cerrahi işlemin 30 günü içinde veya protez materyali implante edilirse 90 gün içinde cerrahi insizyonda veya yakınında meydana gelen ameliyat prosedürüyle ilişkili enfeksiyon olarak tanımlayan kriterler geliştirmiştir.

Kronik kemik enfeksiyonları, ortopedi ve travmatoloji alanındaki cerrahide en önemli sorunlardandır ve sadece gelişmekte olan toplumların sorunu değildir. 
\%1-50 arasında enfekte olabilen açık kırık olguları, implant ilişkili enfeksiyonlara bağlı osteomiyelit olguları ve diyabetik ayak ülserleri de dikkate alınırsa, bu sorunun tüm dünyada yaygın olduğu görülecektir. İmplantla ilişkili enfeksiyonlar, kemik doku destrüksiyonu, implant yetmezliği, amputasyon ve hatta genel sepsise yol açabileceğinden hem hastalar hem de sağlık hizmeti sağlayıcıları için çok önemli bir sorundur. Bu enfeksiyonlarda hekim, çoklu cerrahi müdahalenin gerekliliği, hastada uzun süreli sıkıntı ve kısıtlamalar ve nadiren istenmeyen sonuçlar ve daha yüksek mortalite olasılığı ile karşı karşıyadır. İmplantla ilişkili enfeksiyonların önlenmesi, bu komplikasyonun ortaya çıkmasıyla ilişkili ekonomik, sosyal ve psikolojik sorunlar nedeniyle yaşamsal önem taşımaktadır. Birçok çalışmada metalik implantların yüzeylerinin hidroksiapatit ile kaplanarak kemik ile osseointegrasyonu arttırdığı gösterildiğinden günümüzde metalik implantların biyolojik özelliklerini geliştirmek için sıklıkla kalsiyum fosfat seramikleri kullanılmaktadır. Bir sonraki mantıksal adım, bu yüzeylere antimikrobiyallerin eklenmesi idi. Böylece implant yüzeyinde bakteri kolonizasyonu önlenecek ve enfeksiyon için nidus bölgesinde yüksek konsantrasyonda antibiyotik sağlanacaktır.

Üniversitede biyomalzeme mühendisleri ile birlikte yaptı̆̆ımız multidisipliner çalışmalar ile metal implantların yüzeylerini kaplamak için antimikrobiyal özellikli Ag + iyon katkılı kalsiyum fosfat bazlı toz geliştirildi. ${ }^{[8,9]}$ Metalik implantların gümüş iyon katkılı seramik nanopowder kaplamasının, kaplanmamış implantlara kıyasla bakteri kolonizasyonuna karşı direncin artmasına neden olduğu gösterildi. Daha sonra bu tozla yapılan kaplamaların invitro ve hayvan çalışmalarının başarılı olması üzerine, geliştirilen antimikrobiyal kaplama klinikte gönüllü 36 hastada denenmiştir ${ }^{[10,11]}$. Denenen bu kaplamanın ilk sonuçlarının başarılı olduğu bildirilmiştir. Aynı kaplama malzemesi kendi başına yapay kemik grefti olarak da kullanılabilmektedir. Geliştirilen antimikrobiyal özellikli yapay kemik grefti gönüllü hastalar üzerinde denenmektedir.

\section{KAYNAKLAR}

1. Köse N. Gümüş Iyon Katkılı Kalsiyum Fosfat Esaslı Antimikrobiyal Özellikli Biyoseramik Yapay Kemik Dokusu. PATENT BELGESI - No: TR 201618844 B. https://portal. turkpatent.gov.tr/anonim/arastirma/patent/detayli

2. Ewald A, Glückermann SK, Thull R, Gbureck U. Antimicrobial titanium/silver PVD coatings on titanium. Biomed Eng Online 2006;5:22. Crossref

3. Chen W, Liu Y, Courtney HS, Bettenga M, Agrawal CM, Bumgardner JD, Ong JL. In vitro anti-bacterial and biological properties of magnetron co-sputtered silver-containing hydroxyapatite coating. Biomaterials 2006;27:5512-7. Crossref

4. Gosheger $G$, Hardes J, Ahrens $H$, Streitburger A, Buerger $H$, Erren M, Gunsel A, Kemper FH, Winkelmann W, Von Eiff C. Silver-coated megaendoprostheses in a rabbit model--an analysis of the infection rate and toxicological side effects. Biomaterials 2004;25:5547-56. Crossref

5. Köse N, Çaylak R, Pekşen C, Kiremitçi A, Burukoglu D, Koparal S, Doğan A. Silver ion doped ceramic nano-powder coated nails prevent infection in open fractures: In vivo study. Injury 2016;47:320-4. Crossref

6. Secinti KD, Ayten M, Kahilogullari G, Kaygusuz G, Ugur HC, Attar A. Antibacterial effects of electrically activated vertebral implants. J Clin Neurosci 2008;15:434-9. Crossref

7. Guo C, Xue J, Dong Y. Chapter 10: Hydroxyapatite-silver nanobiomaterial. Grumezescu AM, editor. Nanobiomaterials in Hard Tissue Engineering. William Andrew Publishing; 2016. p.297-321. Crossref

8. Bostancıoğlu RB, Peksen C, Genc H, Gürbüz M, Karel FB, Koparal AS, Dogan A, Köse N, Koparal AT. Analyses of the modulatory effects of antibacterial silver doped calcium phosphate-based ceramic nano-powder on proliferation, survival, and angiogenic capacity of different mammalian cells in vitro. Biomed Mater 2015;10:045024. Crossref

9. Köse $N$, Köse AA, Application of Nanomaterials in Prevention of Bone and Joint Infections. In: Rai M, Kon K, editors. Nanotechnology in Diagnosis, Treatment and Prophylaxis of Infectious Diseases, USA: Academic Press; 2015. p.107-17. Crossref

10. Köse N, Otuzbir A, Pekşen C, Kiremitçi A, Doğan A. A silver ion-doped calcium phosphate-based ceramic nanopowdercoated prosthesis increased infection resistance. Clin Orthop Relat Res 2013;471:2532-9. Crossref

11. Köse N, Köse A, Bayrak C, Sevencan A, Akyürekli AG, Koparal T, Doğan A. The Use of Silver Ion Doped Calcium Phosphate Based Ceramic (Silveron ${ }^{\circledR}$ ) Coated Implants for Preventing Implant Related Infection. Asya Pasifik Ortopedi Birliği Kongresi 2018 (APOA 2018) Antalya, Turkey. 